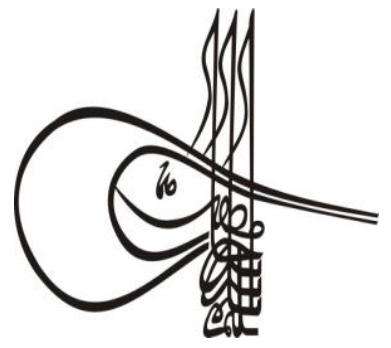

Received/Geliş: 01.08.2019
Turkigh Studies

\section{Language and Literature}

Volume 14 Issue 3, 2019, p. 1205-1223

DOI: 10.29228/TurkishStudies. 29168

ISSN: 2667-5641

Skopje/MACEDONIA-Ankara/TURKEY

Research Article / Araştırma Makalesi

Article Info/Makale Bilgisi

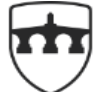

INTERNATIONAL BALKAN UNIVERSITY

EXCELLENCE FOR THE FUTURE IBU.EDU.MK

\title{
ETORİKSEL ANALİZ ÇERÇEVESİNDE SPOR KULÜBÜ BAŞKAN ADAYLARININ KONUŞMALARININ İNCELENMESİ
}

\author{
Başak GEZMEN* - İhsan EKEN**
}

\begin{abstract}
öz
İkna kavramı, geçmişten günümüze sosyal bilim çalışmalarında üzerinde sıkça durulan bir konudur. Günümüzde birçok önemli konuşmacı, siyasi lider, akademisyen için güzel, etkili ve çarpıcı konuşma yapmak önem teşkil etmektedir. Bu noktada, retorik kavramı ve ikna edici iletişim çalışmaları giderek önemini ve etkinliğini arttırmaktadır. Retorik, ikna edici her iletişim türü için geçerli olan, bireylerin düşünce, duygu ve davranışlarını etkilemek için kullanılan hitabet sanatıdır. Bir etkileme aracı olarak işlevini sürdüren retorik, güzel ve etkili biçimde söz söyleme üzerinde durmaktadır. Aristoteles'in Retorik adlı eseri çok eski yüzyıllardan beri etkisini hiç yitirmeden birçok araştırmacı tarafından üzerine çalışan bir eserdir. Aristoteles Retorik'te ikna için önemli bir araç olarak görülen retorik kavramını Ethos, Pathos ve Logos olarak sınıflandırmıştır ve diyalog ve etik kurallara eş değer olarak değerlendirmektedir.
\end{abstract}

Bu çalışmada, Türkiye'nin en önemli sivil toplum örgütlerinden birisi olarak görülen Fenerbahçe Spor Kulübü'nün, "2-3 Haziran 2018 Seçimli Olağan Genel Kurul Toplantısı"nda yer alan iki adayın konuşması Retoriksel açıdan analiz edilecektir. Aziz Yıldırım, Fenerbahçe Spor Kulübü'nde ilk kez 15 Şubat 1998'de başkan seçilmiş ve bu seçime kadar girdiği 12 kongreyi kazanmıştır. Aziz Yıldırım, 20 yıllık bu süreçte Fenerbahçe Spor kulübünü yöneten ve Türk spor hayatına yön veren isimlerden biridir. Araştırmada önem teşkil eden konulardan birisi Fenerbahçe Spor Kulübü’nün, "2-3 Haziran 2018 Seçimli Olağan Genel Kurul Toplantısı'na kadar Türkiye'deki seçimli genel kurulların 5-10 bin

Dr. Öğr. Üyesi, İstanbul Medipol Üniversitesi, E-posta: bgezmen@medipol.edu.tr

Dr. Öğr. Üyesi, İstanbul Medipol Üniversitesi, E-posta: ieken@medipol.edu.tr 
kişilik delegelerin katılımıyla gerçekleşmiş olmasıdır. Bu seçimli genel kurulda rekor seviyede delege oy kullanmıştır.

Kongre sonunda 20 yılı aşkın bir süreçte Fenerbahçe Spor Kulübünü başkanlığını yapan Aziz Yıldırım'ın, seçimli olağan genel kurulda başkanlığı sona ermiş ve yeni Başkan Ali Yıldırım Koç olmuştur. Kongrenin ana konuşmacıları başkan Aziz Yıldırım ve başkan adayı Ali Yıldırım Koç'un değişim ekseninde gerçekleştirecekleri, öngörülerine dayanan konuşmaları retoriksel çerçevede ilgili başlıklar üzerinde değerlendirmeye alınmıştır. Çalışmada iki başkan adayının seçim öncesi konuşma metinleri incelemeye alınmıştır. Amaç retoriksel analiz ekseninde en sık kullanılan retorik unsurlarını, metinler üzerinden ortaya çıkarmaktır. Konuşmalar inandırıcılık, mantıksal olarak ispatlama ve dinleyicilerin duygularına hitap etme noktasında örneklerle değerlendirilmiştir. Aziz Yıldırım konuşmasında genel olarak 3 Temmuz'da yaşanan şike olayları sürecine değinmiştir. Ali Yıldırım Koç, konuşmasında temel olarak geçmiş yönetimin hatalarından bahsetmekte ve kendisinin seçilmesi durumunda yeni yönetimin ortaya koyacağ 1 değişim ve dönüşümlerden bahsetmiştir.

Anahtar Kelimeler: Retorik, Fenerbahçe, Seçim kongresi konuşmaları, İkna

\title{
AN INVESTIGATION OF THE SPEECHES OF THE PRESIDENTIAL CANDIDATES OF SPORT CLUBS IN THE FRAME OF RHETORIC ANALYSIS
}

\begin{abstract}
Persuasion is a subject that has frequently been emphasized in social science studies from past to present. Today, it is crucial to deliver a beautiful, effective, and memorable speech for many distinguished speakers, political leaders, and academics. At this point, communication studies focusing on persuasion emphasize the concept of rhetoric more. Rhetoric is an art that is necessary for every persuasive communication and is used to influence the thoughts, feelings, and behaviors of individuals. Rhetoric, which functions as a tool of influence, focuses on speaking beautifully and effectively. In 'Rhetoric,' Aristotle defines the concept of rhetoric, which is seen as an essential tool for persuasion, as Ethos, Pathos, and Logos and evaluates the concept of rhetoric as equivalent to dialogue and ethical rules.

In the present study, the speeches of two presidential candidates speaking at the Ordinary General Assembly Meeting of Fenerbahce Sports Club, which is considered to be one of the most important nongovernmental organizations in Turkey, will be analyzed. Aziz Yildirim, who was elected as the president to Fenerbahce Sports Club, for the first time on 15 February 1998, won the next 12 presidential elections. In this process, he has been one of the names who ran Fenerbahce Sports Club and directed Turkish sports life. One of the issues to be underlined in the research is that the presidential elections of no sports club held until today have had as many members as the elections held at Fenerbahce Sports Club. As a result of the Congress, Aziz Yildirim, who had been the president of Fenerbahce Sports Club for over 20 years, lost to Ali Yildirim
\end{abstract}


Koc, who was elected the new president. The speeches of President Aziz Yildirim and presidential candidate Ali Yildirim Koc, the main speakers of the Congress, will be evaluated in the rhetorical framework.

\section{STRUCTURED ABSTRACT}

Persuasion, which is defined as making someone to believe, convincing and deceiving on a subject, is seen as an art and is actually considered as a science (TDK, t.y.). Today, in many training programs, seminars and similar areas, activities to improve persuasion ability are performed.

Persuasion, which is defined as the ability to change thoughts, feelings and behaviors by using word, image, sound, smell, taste, touch and similar sensations, is an indispensable concept for all living things. People can change the opinions of others through persuasion actions, but they cannot change the facts. Nevertheless, by changing the meanings attributed to realities, they can make them significant or insignificant. Persuasion is a genre, in which people are interested, in many areas of mass communication. Advertisers to sell a product, politicians to influence voters, doctors to inform the patient about health-related issues or in all similar occasions use persuasion. All of these people use mass media messages to make some of the changes they want to create in other people (O'Keefe, 2002).

We often try to persuade people or institutions to believe in certain issues by using our ability to persuade. Which persuasion, impact strategies the institution managers use is also important in achieving success and in the process of creating value and getting the reputation of the organization. Persuasion, as a process of mental change, forms the basis of Aristotle's work named Rhetoric. Rhetoric, which is defined as the art of using language correctly and convincingly in influencing the thoughts, behaviors and feelings of individuals, is valid for every kind of convincing communication. It is frequently used in oral and written communication fields, in the fields of painting and music, in advertisements, videos, virtual media, movies, etc. (Suler \& Zakia, 2018)

Nowadays, considering the sociological and psychological values it carries and that it maximizes competition culture, the power of football is better understood. The main factors triggering the power of football are that the scope of the sector, which was initially financially created, gradually increases, as well as, that it can be used as a political tool. The breadth of its impact and the distinctive popular culture it created cause football be followed by a wide audience. In June 2018, presidential elections of Fenerbahçe Sports Club were held. Over nearly 20 years, Aziz Yildirim has managed one of Turkey's most important non-governmental organizations, namely Fenerbahçe Sports Club. The other presidential candidate is Ali Yıldırım Koç who is the vice president of the executive board of Koç Holding, one of the most important holdings of Turkey. The discourses and promises in the speech of the two presidential candidates were followed by many segments of the society.

Many concepts and terms related to rhetoric are used. In the rhetorical analysis and rhetorical decodings, it is not possible to talk about a uniform model or coding. (Bıçakç1, 2012). In the present study, 
determined speech texts are analyzed in the axis of three main elements of Aristotle's rhetoric: ethos, pathos, and logos. In addition, it was determined in the study that identification, giving examples, showing evidence, using metaphors, using mythonomy, mocking (irony), creating fear and anxiety, creating herd mentality, using reliable sources, giving background information, using nicknames, personification, trilogy rule, constructing parallel structures, using pronouns, using numerical information, praise or eulogy, alliteration, in other words, sound repetition are the most commonly used rhetorical elements. Elements in rhetorical analysis were evaluated within the framework of classifications of Devran (2010) and Bıçakçı (2012).

Speeches of Aziz Yildırım, the current President of Fenerbahçe Sports Club, that is one of Turkey's most important non-governmental organizations over nearly 20 years, and Ali Yıldırım Koç, the vice president of the executive board of Koc Holding that is Turkey's one of the most important holdings, on 2-3 June 2018, at the Fenerbahçe Sports Club Ordinary Elective Assembly were analyzed rhetorically.

Aziz Yildirim, in his speech, refers to the process of match-fixing events in general which occurred on 3 July. He emphasized that he had spent one year in prison in the period of 3 July. Yildırım, who pointed out that he sometimes made wrong decisions to repair the deteriorating morale of the community after this process, made a self-criticism, at this point. Ylldirım frequently emphasizes that he does everything himself. Besides, he found others guilty in all mistakes and cast out them from the club through discrediting. The rhetorical elements that Yildirim uses most in his speech are metaphor, giving examples, background information, reliable source and simile. Apart from these, Yıldırım often used elements such as pronoun, mocking, mythonomy, numerical information and so on. In some sections, he tried to draw a different picture by comparing himself with the opposition and to convince the members of the congress. During his speech, the president often break off his speech by discussing verbally with the members of the congress.

In his speech, Ali Yildirim Koç basically mentions the mistakes of the past management and talks about the changes and transformations that the new management will bring in case that he is elected. In this context, the most commonly used concepts he used are sustainability, balance, and continuity. In addition, when Koç speaks of the different mentality of the new administration, he points out that a new era which makes self-criticism and which is rational and consistent, democratic, accountable and without oppression will begin. Koc has a critical and incriminating attitude in his discourse. Especially the fact that Yildirim does not take into consideration the human element, his frequently repeated self-centered expressions, his way of sending footballers and coaches form the basis of the criticism points. At this point, Koç also makes self-criticism in decision-making processes in which he is involved within the term. In the speeches, the most frequently used elements used by presidential candidates were metaphor, giving examples, giving background information and, from time to time the elements such as mythonomy, pronoun, eulogy, use of reliable sources, creating herd mentality, mocking, trilogy rule, giving numerical information were used.

Keywords: Rhetoric, Fenerbahce, Electoral Congress Speeches, Persuasion 


\section{Giriş}

Bir konuda birinin inanmasını sağlama, inandırma, kandırma olarak tanımlanan ikna, bir sanat olarak görülmekle birlikte aslında bir bilim olarak da değerlendirilmektedir (TDK, t.y.). Günümüzde birçok eğitim programı, seminer ve benzeri alanlarda ikna yeteneğinin geliştirmesine yönelik çalışmalar yapılmaktadır.

Belirli yöntemlerle çeşitli fikirler, tutumlar ve davranışlar değiştirilebilmektedir. Kişisel gelişim alanının en önemli konularından biri olan ikna sürecinde, tutumlar ekseninde doğru ikna stratejisini oluşturmak önem teşkil etmektedir.

Çevremizde çoğu zaman ikna etme kabiliyetimizi kullanarak kişileri veya kurumları bazı konularda inandırmaya çalışırız. Kurum yöneticilerinin hangi ikna, etki taktiklerini kullandıkları da başarıya ulaşmada ve kurumun değer yaratma ve itibar sağlama sürecinde önemlidir. Zihinsel bir değişim süreci olan ikna, Aristoteles'in Retorik adlı eserinin de temelini oluşturmaktadır. Bireylerin düşünceleri, davranışları ve hissettiklerini etkilemede dilin doğru, ikna edici şekilde kullanım sanatı olarak tanımlanan retorik, ikna edici her iletişim türü için geçerlidir. Sözlü ve yazılı alanlarda, resim, müzik alanlarında, reklamlarda, videolarda, sanal ortamda, filmlerde v.b alanlarda sıklıkla kullanılmaktadır (Suler \& Zakia, 2018)

Tüm dünya da olduğu gibi Türkiye'de de futbol büyük kitleler tarafindan takip edilmektedir. Bu bağlamda Türkiye'de büyük kulüpler (şampiyon olmuş takımlar) adı altında yer alan takımların yöneticileri ve başkanları halk üzerinde önemli bir etkiye sahiptir. Yöneticilerin maçlardan sonraki, transfer dönemlerindeki ve özellikle kongre sürecinde yapmış oldukları konuşmalar taraftarın ve halkın doğru yönlendirilmesi açısından önem teşkil etmektedir. 2-3 Haziran 2018 tarihinde Fenerbahçe Spor Kulübünün Seçimli Olağan Genel Kurul Toplantısı yapılmıştır. Olağan Genel Kurul Toplantısında Mevcut Başkan Aziz Yıldırım ile başkan adayı Ali Yıldırım Koç’un konuşmaları hem Fenerbahçe camiası hem de Türk halkı tarafindan ilgiyle takip edilmiştir.

Çalışmada iki başkan adayının seçim öncesi konuşma metinleri incelemeye alınmıştır. Amaç retoriksel analiz ekseninde en sık kullanılan retorik unsurlarını, metinler üzerinden ortaya çıkarmaktır. Konuşmalar inandırıcılık, mantıksal olarak ispatlama ve dinleyicilerin duygularına hitap etme noktasında örneklerle değerlendirilmiştir.

\section{1. İletişim Sürecinde İknanın Önemi}

Makalede bilgi, düşünce ve davranışların aktarılması olarak tanımlanabilen iletişim (İlal, 1997, s. 9), birey yaşamının tüm etkinliklerini kapsamaktadır. İnsanoğlunun var olma süreciyle başlayan iletişim, insanlık tarihinin ilk dönemlerinde bireyin ilkel ihtiyaçlarını karşılamak için yapılan faaliyetler iken zamanla gelişen teknolojiyle farklı biçimlere dönüşmüş ve hala da baş döndürücü bir hızda dönüşmektedir. Mağaralara duvarlarına çizilen ilk iletişim biçimleri günümüzde internet ortamı ve sosyal medya mecralarında gerçekleşmektedir. (Aziz, 2013, s. 25) İnsan topluluklarının en önemli özellikleri arasında iletişim biçimlerini öğrenme becerisine sahip olmaları gelmektedir. Her zaman her yerde var olan iletişim toplumsal bir süreçtir. Sosyal bir varlık olan insanlar sözel iletişim becerileri sayesinde davranış biçimlerini değiştirmekte, geliştirmekte ve bu yine sözel iletişimle sosyalleşmektedir. Sözel iletişimde konuşma becerileri ve dinleme becerileri önem taşımaktadır. Toplumda etkili konuşma ve dinleme becerilerine sahip olan birey her zaman aranan, itibar edilen bireyler arasına kolayca girebilmektedir (Misırl1, 2011, s. 38).

İletişimin nihai amaçları karşılıklı anlaşma ve paylaşım sağlamak olmalıdır. İletişim genel anlamda, bireyler arasındaki sürekli doğru ya da yanlış ya da fazla ve eksik olarak haber akışı sağlama sürecidir. Bilgi dağarcığımız bu şekilde oluşur ve gelişimini, sürdürür. Yeni gelen bilgiler eskilerine eklemlenerek başvurulan çevreden alınan iletilerle şekillenmektedir. Bu şekilde oluşan dağarcığımız 
sadece tutum ve davranışlarımızı yönlendirmede değil aynı zamanda, başkaları üzerinde etkili olabilmemizi sağlayan temel bir unsurdur (Z1llığlu, 2003, s. 69-70).

John Adair, etkili iletişim unsurlarını değerlendirirken konuşmanın önemini vurgulamaktadır. Toplumun duygularını harekete geçirmek amaçlı yapılan belagatlı konuşma olarak tanımlanan hitap, ağırbaşlı bir tarzda önemli bir konu üzerine, konuşma kuralları çerçevesinde düzenlenmiş ve genelde kutlama ya da cenazelerde yapılan konuşmalardır. Ayrıca gösterişli konuşmalar da hitap olarak adlandırılmaktadır. Bunlar doğaçlama veya özenle hazırlanmış olabilir. Amaç dinleyici kitlesini alevlendirerek harekete geçirmektir. Hitler'in İkinci Dünya Savaşı öncesi konuşmaları uzun nitelikli nutuklar olarak da adlandırılabilmektedir (Adair, 2013, s. 53). Etkili iletişimde iknanın önemi büyüktür. Aslında ikna iletişimler grift yapıda olarak ilerleyen bir kavram olarak toplumsallaşma sürecinde etkendir. Bireyler yaşam pratiklerinde zaman zaman karsındaki kişiyi ya da grupları ikna etmek durumuyla karşı karşıya kalabilmektedir. İkna sürecinde önceden belirlenmiş niyetler çerçevesinde ilişkiye geçilir. İletişim sürecinde karşı tarafın duygu ve davranışlarını etki amacı gütmesi nedeniyle bu etkileme isteği, ikna amacıyla kurulmuş iletişim biçimini diğer iletişim çabalarından farklılaşmaktadır. Diğer kişi veya kişilerin tutum ve davranışlarını zor kullanarak ve yönlendirerek değil çeşitli akıl yürütme ve kanıtlama taktikleriyle etkileme eylemi şeklinde tanımlanabilmektedir (Yıldırım, 2018, s. 13-14). Retorik genel anlamda etkili ve güzel konuşma sanatıdır. Retorik üzerine oldukça fazla sayıda çalışma yapılmış, kuramlar geliştirilmiştir. Bu çalışmalar arasında konuşmalarda yararlanılacak, ikna etme amaçlı kullanılabilecek yararlanılacak unsurları ele alarak örnekler üzerinden değerlendiren Aristoteles'in Retorik adlı eseri diğer çalışmalara da kaynak teşkil etmektedir (Küçükerdoğan, 2011, s. 19)

Platon'un öğrencisi Aristoteles'in en önemli eserlerinden biri olan retorik, iletişim koşul ve etkileri üzerine genel bir düşünce kapsamında değerlendirmeye alınabilir. Retorik, politik yaşam pratiklerinde, konuşan ve mantığı olan insanın sözü nasıl ve neden etkili bir biçimde yaşam doğasını mükemmelleştirmek için kullanılmaktadır. Retorik, temelde iknayla alakalıdır. İkna belli bir kişi için ikna edici, sokaktaki adamı ikna etmek söz konudur. Amaç, iknanın bilginleri hedef alması değildir (Bourse \& Yücel, 2012, s. 44-45) Aristoteles, diyalektiğin eşdeğeri olarak nitelendirdiği retoriği belli bir duruma özgü elde var olan inandırma yollarını gözlemleme yetisi olarak tanımlamaktadır, Kanıtlarla inandırma bir gösteri sanatıdır. Retorik Aristoteles'e göre diyalektiğin ve etik çalışmaların bir dalı olarak görülebilmektedir. Bireyleri ayrı ayrı ele almayan Retorik, insan topluluklarıyla ve sınıflarla alakadar olmaktadır (Aristoteles, 2001, s. 19-20). Fotoğrafta Retorik, çalışmalarını ele alan Jacques Durand, özet anlamda retoriği sahte konuşma sanatı olarak tanımlamaktadır. İki kademeli dil olarak oyunu şekillendirdiği belirtilen retorikte uygun dil ve süslü dil kullanılmaktadır. Süslü olan dilde söylenenin çok daha basit ve tarafsız, doğrudan anlatıldığı farz edilmektedir (Burgin, 2013, s. 78).

İkna hem bir sanattır hem de bilimdir. Aristoteles ikna sürecinde üç temel unsur üzerinde durmaktadır. Bunlar Ethos, Pathos ve Logostur. Ethos(etik), bir kişinin karakteri, inandırıcılık boyutu, ahlaki değerleri, bilinir birisi olup olmadığı anlamındadır. Bu bağlamda, eğer herhangi bir kişiye karşı güveniniz yok ise konuşma ne derece etkili olursa olsun ikna süreci etkili olmayacaktır. Bir kişiye inanmanız ve güvenmeniz ikna sürecinde ana etkenlerdendir. İnandırıcılık nasıl sağlanabilmektedir? İnanırlık, güven ve uzmanlık birleşiminde gerçekleşmektedir. İnanılır güvenilir olma kişinin zamanla kazandığı özelliklerdendir. İnandırıcı olmak için bireyin düşüncelerinin göründüğü gibi algılanması gerekmektedir (Küçükerdoğan, 2011, s. 19). Hoşa giden beğenilen istekleri kapsayan hislerle alakalı olan pathos, iknada psikolojik durumlar şeklinde incelenmektedir. Kişi veya kişiler herhangi bir durumda ikna edilmeye çalışlacaksa hisler, duygular, psikolojik durum çok iyi bir şekilde gözlemlenerek analiz edilmelidir (Karadoğan, 2003). Logos(mantık) ise alıntılı cümleler ya da kelimeler, istatiksel veriler, sayısal değerlerin ön olana çıkarılması, kelimelerin seçilmesi olarak tanımlanmaktadır. Bu üç özellikten hangisinin önce geldiği tartış1labilir ancak günümüzde de bu önemli etkenler çerçevesinde değerlendirmeler yapılmaktadır (Tekinalp, 2016, s. 7-8). 
Günümüzde birçok lider, önemli konuşmac1, karakterleri, inandırıcılık boyutları, ahlaki değerleri, hisleri ile duyguları başarılı yönetme, etkin bir mantıksal çerçeve oluşturma ve geliştirme konularını doğru ve başarılı bir biçimde kullanmaktadır.

\section{2. İkna ve İkna Kuramları}

Kelime, görsel, ses, koku, tat, dokunma vb. duyguları kullanarak düşünce, duygu ve davranış değiştirme yeteneği olarak tanımlanan ikna tüm canlılar için vazgeçilmez bir kavramdır. İnsanlar ikna eylemleri sayesinde karşısındaki kişilerin düşüncelerini değiştirebilir, ancak gerçekleri değiştiremez. Bunun yanında gerçekliklere verilen anlamları değiştirerek onları önemli veya önemsiz kılabilmektedir. İkna, kitle iletişimin birçok alanında insanların ilgilendiği bir türdür. Reklamcılar, bir ürünü satmak için, politikacılar, seçmenleri etkilemek için, doktorlar sağlıkla ilgili konularda hastayı bilgilendirmek için vb. tüm olaylar için iknayı kullanırlar. Bu kişilerin tamamı, diğer insanlarda oluşturmak istedikleri bir takım değişiklikleri değiştirmek için kitle iletişim mesajlarını kullanırlar (O'Keefe, 2002)

İkna geçmişten günümüze hatta geleceğe değin insan yaşamının bir parçası olacaktır. İnsanlar her zaman, diğer insanları hatta aile üyeleri ve yakın arkadaşlarını etkilemeye çalışacaklardır. Aristoteles'in retorik çalışması ile başlayan ikna günümüze değin birçok araştırmacı tarafından ele alınmıştır. İkna ile yapılan çalışmalarda iknayı etkileyen faktörler üzerindeki çalışmalar önplana çıkmıştır. İkna konusu çerçevesinde yapılan akademik çalışmalar incelendiğinde, ilk çalışmaların Aristoteles'in Retorik kavramına değin sürdügü görülmüştür. İkna ile ilgili birçok araştırmacı tarafından farklı kuramlar geliştirilmiştir. İknayı daha iyi açıklamak için bu kuramları incelemekte yarar bulunmaktadir.

Tutum kavramı: "Deneyimlerle örgütlenmiş, iliş̧kili olan tüm durum ve nesnelere karşı bireyin edimleri üzerinde emredici ya da dinamik olarak etkileme gücü olan zihinsel ve duygusal hazırlı durumudur" (Allport, 1954; akt. Severin \& Tankard, 1994). Tutumlar doğrudan gözlenebilir bir özelliğe sahip değildir ancak kişilerin davranışlarının gözlemlenmesiyle bir çıkarım yapılarak o kişilerin davranışlarına atfedilen bir eğilimdir (Arkonaç, 2001). Tutumlar kişilerin gösterdiği bir tepki şekli değildir bunun dışında daha çok tepki gösterme eğilimidir. Tutumlar olumlu ya da olumsuz davranışlara yol açabilir. Tutumların bireyler açısından çeşitli işlevleri bulunmaktadır. İnceoğlu, (2000, s. 14) söz konusu işlevleri dörde ayırmaktadır; Bilgi İşlevi, Yararlı Olma İşlevi, Değer Etkileyici İşlevi, Ego Koruma İşlevi

Hovland'ın Ordu Araştırması: Tutum değişikliğine yönelik yaklaşımı başka bir değişle öğrenme kuramı ve pekiştirme kuramı yaklaşımıdır. Hovland, tutumların değiştirildiğine ve aynı şekilde tutumların öğrenme sürecinde değiş̧irildiğine inanır. 2. Dünya Savaşı sırasında Amerika Birleşik devletleri Ordusu üzerinde filmler ve diğer kitle iletişim biçimleriyle askerlerin güdülemesi ve eğitimi için kullanılmıştır (Severin \& Tankard, 1994).

Tek-Yanlı ve Çift-Yanlı İletiler: Hovland ve yardımcıları aynı iletinin iki uyarlamasını üretip ikinci tür bir araştırmaya yöneldiler. Yalnızca bir değişkende farklılık yaratarak tek yanlı ve çift yanlı iletilerin etkinliğini ölçen bir deney düzenlediler. Hovland ve yardımcılarının deney sonucunda eğitim seviyelerine göre sonuçları incelediğinde, daha az eğitimli kişilerde tek yanlı iletinin daha etkili ve daha eğitimli kişilerde çift yanlı iletinin daha etkili olduğu görülmektedir. Ayrıca başlangıçtaki tutumlara göre sonuçların incelenmesi göstermiştir ki, başlangıçta ileti yanlısı kişilerde tek yanlı ileti daha etkili ve başlangıçta iletiye karşı olan kimselerde ise çift yanlı ileti daha etkilidir (Severin \& Tankard, 1994).

Yale İletişim Araştırma Programı: Tutumun değiştirilmesi için öncelikle verilen mesajın öğrenme sürecindeki aşamalara değinilerek, bu sürecin değerlendirilmesi gerekir. Yale İletişim Araştırma Programında özellikle tutumun değiştirilmesi için mesaj sürecindeki aşamalarda yaşanan değişkenlere önem verilerek, bu süreç üzerindeki değişkenler üzerinde durulmuştur. Bu program "artan 
ya da azalan ikna edici iletişim türlerinin etkililiğini ölçecek bilimsel önermeler geliştirmeyi amaçlamaktadır (Severin \& Tankard, 1994).

Kaynak Güvenirliliği: Düşüncenizle ya da ürününüzle ilgili konuşacak etkili kaynağın seçimi, temel olarak tanıklık adı verilen propaganda aracıdır. Hovland ve Weiss (1951) kaynak güvenirliliğinin etkisini ölçmek için bir deney hazırladılar. Deneklere belirli süreler testler yaptıktan sonra şu sonuçlara ulaşıldı. Düşünce değişikliği miktarı güvenirliliği yüksek ve düşük kaynaklar için hemen hemen eşitti. Fakat güvenirliliği düşük kaynak için iletişimden sonraki teste göre dört hafta sonraki testte daha büyük miktarda düşünce değiş̧ikliği görülmüştür.

Korku Çekiciliği: İnsan yaşamında çok önemli bir yere sahip olan korku duygusu, hayatımızın birçok alanına yansımıştır. Korku, bir tehlikeyi ifade eden ya da en azından ima eden tehdit karşısındaki duygusal tepkidir. Reklamda korku çekiciliği, bireylerin tutum ve davranışlarına etki etmek için bir ürünün, hizmetin ya da düşüncenin benimsenmesi ya da benimsenmemesi, alınması ya da alınmamas1 durumunda ortaya çıkacak tehlikenin ve risklerin görsel ya da yazılı olarak reklamlarda anlatılmasını ve bu yolla hedef kitlelerin harekete geçirilmeye çalışmasını ifade eder. "Korku, geçmişten günümüze dek sigara, alkol, uyuşturucu gibi zararlı alışkanlıkların önlenebilmesi”, belli siyasal davranışların geliştirilmesi, ticari fayda elde edilebilmesi gibi çeşitli amaçlar doğrultusunda kullanılmıştır (Elden \& Bakır, 2010).

Aşılama Kuramı: Aşılama, terim olarak "Bir hastalığın daha sonraki bir zamana ertelenmesi ya da hazırlanılması için yapılan küçük dozda enjeksiyon"dur. İnsan vücuduna aşı yoluyla yapılacak antikorlar, insan vücuduna uyum sağlayarak daha sonraki süreçte mikroplar tarafından oluşabilecek bir hastalığa karşı direnç oluşturabilir (Bir, 2005). 50'li yıllarda Kore'de esir düşen Amerikan askerlerine uygulanan beyin yıkama tekniklerinden etkilenen McGuire, insanların propagandaya karşı nasıl direnç sağlanabilir ve bu konu hakkında neler yapılabilir konusu üzerinde çalışmalar yürütmüştür. McGuire araştırmasında tıptaki aşılama yöntemine benzer bir çalışma yürütmüştür. Aşılama kuramında bir görüşe direnç sağlanırken, direnç sağlanan görüşe karşı olan görüşü güçlendirerek yeni bir model önermektedir.

Katz'ın İşlevsel Yaklaşımı: Katz'ın yaklaşımı tutumun nasıl sağlanabileceğine ilişkin sorular sorarak, tutumların sahip olduğu işlevsel özellikler üzerinden cevap bulmaya çalışmaktadır. Kişilerin tutumlarının değişmesi için tutumun öncelikle hangi işleve hizmet ettiğini bilmek gerekir. Katz'a göre tutumun işlevini bilmeden yapılacak bir ikna çalışması, tüm çalışmayı boşa çıkarabilir.

Tutumlar ve Davranışlar: İletişim alıcı, verici ve bir kanal çerçevesinde gerçekleşen bir süreçtir. İletişimi başlatan kişi, mesajı iletmek istediği tarafın tutum ve davranışlarını etkileyerek onları ikna etmeyi amaçlamaktadır. Bu süreç ikna etme amacıyla kurulduğundan dolayı diğer iletişim süreçlerinden farklılık göstermektedir. Örneğin yolda gördüğünüz bir kişiye adres sorduğunuz zaman, karşıdaki kişiyi ikna etmeye çalışmazsınız.

Düşük İlginlik Kuramı: Tutum değişikliğinin davranış değişikliğinden önce oluşmasına dair normal düşünce, televizyon reklamlarının etkileri ile ilgili bir kuram tarafından tersine çevrilmiştir. Herbert Krugman, insanların televizyondaki iletileri, basılı medyadaki iletilerden farklı biçimde işlediğini söyleyen bir kuram geliştirmiştir. Krugman, televizyonun beynin sol yarısı ile değil de sağ yarım küresi ile değerlendirildiğini savunur. Bu tür bilgi işlemesi düşük ilginlik veya ilginsizlikle olur. Krugman bu yolla işlenen iletilerin bellekte depolandığını, ancak yeniden geri çağrılmadığını söyler. Krugman, düşük ilginlik kuramı, maruz kalma tekrarının, davranışı ateşleyecek tetik oynayana kadar görülebilir bir etkisi olmadığını ortaya çıkarır ifadesini kullanır. Krugman'ın ortaya çıkardığı kuram, biraz bilinçaltı algılamaya benzemeye başlar (Severin \& Tankard, 1994).

İkna Teknikleri: Mizahi çekicilik; pek çok konuşmacı, mizahi bir öykü ile başlamanın önemine açıkça inanmaktadır. Mizah dikkat çekmede, iletişimci için hoşlanma yaratmada ve bunun gibi 
konularda tutum ya da davranış değişikliği yaratmaktan daha etkilidir. Cinsel çekicilik; reklamlarda cinsellik yaygın olarak kullanılmasına rağmen, bunu kullanmada bazı riskler bulunmaktadır. Bazı izleyiciler tarafından bu hoş karşılanmayabilir, yanlış algılanabilir ya da gözden kaçırılabilir, izleyicileri reklamın gerçek amacından uzaklaştırabilir. Çok az çalışma reklamda cinsellik ile marka anımsama ya da ürün satışı sırasında olumlu bir ilişki olduğunu gösterir. Reklam iletisinin yoğun tekrarı; çoğu kitle iletişim iletileri, özellikle reklamlar, ticari ya da politik yaygın olarak tekrarlanır. Bütün izleyiciler aynı anda televizyon izlemeyeceklerdir ya da basında bütün okuyucular bir tek reklamı görmeyecektir. Tekrar, izleyicilerin iletinin kendisini anımsamalarına yardım edebilir (Severin \& Tankard, 1994).

\section{Amaç ve Önem}

Günümüzde, içinde bulunduğu sosyolojik ve psikolojik değerler dikkate alındığında ve rekabet kültürünü en üst düzeye çıkardığı düşünüldüğünde futbolun gücü daha iyi anlaşılmaktadır. Futbolun gücünü tetikleyen ana unsurlar politik bir araç olarak kullanılabilmesinin yanında finansal olarak yaratılmış sektörün alanının giderek artmasıdır. Etki alanının genişliği ve oluşturduğu kendine özgü popüler kültür futbolu geniş kitlelerce takip edilmesini sağlamaktadır. 2018 yılı haziran ayında Fenerbahçe Spor Kulübü'nün başkanlık seçimleri gerçekleşmiştir. Aziz Yıldırım yaklaşık 20 yılı aşkın bir süredir Türkiye'nin en önemli sivil toplum kuruluşlarından biri olan Fenerbahçe Spor Kulübü'nü yönetmektedir. Diğer başkan adayı ise Türkiye'nin en önemli holdinglerinden biri olan Koç Holding Yönetim Kurulu Başkan Vekili Ali Yıldırım Koç'tur. İki başkan adayının konuşmalarındaki söylemler, vaatleri toplumun birçok kesimi tarafından takip edilmiştir.

Çalışmada amaç, 2 önemli başkan adayının konuşmalarının ikna edici unsurlar çerçevesinde değerlendirilmesi olacaktır. Bu bağlamda retoriksel çözümleme çerçevesinde kullanılan ilgili başlıklar metinler üzerinde sınıflandırılarak analiz edilmiştir.

\section{Yöntem}

Retorik ile ilgili birçok kavram ve terim kullanılmaktadır. Retorik analizinde ve retoriksel çözümlemelerde tek tip model veya kodlamadan söz etmek mümkün olmamaktadır (Bıçakçı, 2012). Çalışmada, belirlenen konuşma metinleri Aristoteles retoriğindeki üç ana unsur olan ethos, pathos ve logos ekseninde çözümlenmektedir. Ayrıca araştırmada Tablo 1'de yer alan en sık kullanılan retoriksel unsurlar da dikkate alınmaktadır. Retoriksel çözümlemedeki unsurlar Devran (2010) ve Bıçakçı (2012)'nın sınıflandırmaları çerçevesinde değerlendirilmeye alınmıştır. 
Tablo 1: Siklıkla Kullanılan Retoriksel Unsurlar

1) Tanımlama: Metnin okuyucular tarafından daha iyi algılanması için metin içerisinde geçen ifadelerin açık ve net bir şekilde aktarılmasıdır.

2) Örnek verme: Argümanları kuvvetlendirmek ve açıklama yapmak için başvurulan bir anlatım tekniği.

3) Kanıt gösterme: Kendi görüşünü savunucu ve haklı olduğunu gösterici yöntem biçimidir.

4) Metafor kullanma: Bir şeyi başka bir şeyle benzeterek izah etme, açıklama.

5) Mitonomi kullanma: Bir parçanın bir bütünü temsil etmesi.

6) Alaya alma (ironi yapma): Kullanılan kelimelerle ifadenin zıddını açıklamayı amaçlar.

7) Korku ve endişe yaratma: Korku ve endişe gibi olumsuz hisler oluşturmak için kullanılan yöntem.

8) Sürü mantığı yaratma: Bazı durumlarda bireylerin toplumdan dışlanmak, izole olmamak için bütünün fikir, tutum ve davranışlarına paralel hareket etmesidir.

9) Güvenilir kaynak kullanma: İnandırıcılık arttırılmasını sağlamak için başvurulan kaynakların bütünü.

10) Arka plan bilgi verme: Olaya iliş̧in geçmişe dönük tarihsel bilgi akışı sağlamak

11) Lakap kullanma: İsim takma.

12) Kişiselleştirme: Varlıklar, bir kişiymiş̧̧esine gösterilerek karmaşık bir olayın daha kolay anlaşılmasını sağlamak.

13) Üçleme kuralı: Üç sözcükten oluşan bir cümle kullanımı

14) Paralel yapılar kurma: Benzer yapıların bir arada kullanımıdır.

15) Zamirler kullanma: Ben, sen, siz, o ifadelerinin kullanımı.

16) Rakamsal bilgi kullanma: Metinde rakamlar kullanılarak ikna gücünün arttırılması sağlanır.

17) Övgü/methiye: Bir nesneyi yada kişiyi övmek, methetmek.

18) Aliterasyon /ses yinelemesi: Aynı seslerin uyum sağlamak için tekrarlanması.

\section{Bulguların Değerlendirilmesi}

\subsection{Aziz Yıldırım'ın Konuşmasının Retoriksel Çözümlenmesi}

Dönemin Fenerbahçe Spor Kulübü Başkanı Aziz Yıldırım'ın, 2 Haziran 2018 Seçimli Olağan Genel Kurul Toplantısı'nda yaptığı konuşması retorik unsurlar açısından incelediğinde en çok metafor, güvenilir kaynak, benzetme, örnek verme, tanımlama, arka plan bilgisi kullanma gibi unsurlarından yararlandığ 1 görülmüştür. Aziz Yıldırım'ın konuşmasındaki deşifre metnine göre paragraflar tek tek incelendiğinde;

(1) Deşifre metnine göre, ilk paragrafta genel kurulumuz Fenerbahçe'nin ta kendisidir söyleminde mitonomi unsuruna yer verilmiştir. Bu kurul 20 yıl başta olmak üzere birçok defa beni... cümlesinde ise rakamsal bilgiye başvurulmuştur. (2) Aziz Yıldırım konuşmasında Erganili ve öğretmen bir babanın çocuğuyum derken genel olarak sizden biriyim, halk adamıyım izlenimi vermeye çalışmaktadır. (3) Deşifre metninde üç ile numaralandırılan ve alkışlamaya gerek yok, en sonunda alkışlayacaksınız, rahat olun, en sonunda alkışlayacaksınız. cümlesinde ise alaya alma yani ironi yapılmaktadır.

(2) Deşifre metninde dört ile numaralandırılan paragrafın başında çünkü Fenerbahçe elitist seçim yapmadı derken karşı tarafla kıyaslama yapmaktadır. Aynı paragrafta yer alan ruhumuz bir, bir yola baş koyduk derken birlik, beraberlik ve beraber hareket etmeden bahsedilmektedir. Paragrafin devamında anlattığı argümanı kuvvetlendirmek için Türkiye Cumhuriyetinin kuruluşundan bahsetmektedir. Kulüp için hapis yattım derken diğer yönetici ve taraftarları eleştirerek kendisinin büyük bir fedakarlık yaptı̆̆ını söylemektedir. Bu cümlenin devamında kendini överek, her şeyi kendisinin yaptığını vurgulamaktadır. Paragraf içerisinde yer alan retoriksel unsurlar incelendiğinde, Fenerbahçe'nin hamuru ve yedi düvelin işgali söylemlerinde metafor kullanımı yer almaktadır. Bu söylemlerin devamında Fenerbahçe emperyalizmin kuşatmasını kırmak, milli mücadeleyi ateşlemek, 
bağımsız Türkiye' yi kurmak için adanmış ruhlardan bize ulaşan ve içimizde yaşayan bir aşktır cümlesinde olayla ilgili örnekler verilmiştir ve cümlenin devamında Kuvayı Milliye ruhundan bahsederken önceki söylemlerde olduğu gibi metafor unsurundan yaralanmıştır. Bu söylemi takip eden cümlede ise siz kelimesiyle beraber zamir kullanımından yararlanıl ve olayla ilgili arka plan bilgisi verilmiştir. Paragrafı takip eden cümlelerde muhalefetten bahsederken, muhalefeti Ali Yıldırım Koç’a benzetmektedir. Muhalefet benzetmesinden sonra eğer doğru zamanda ile devam eden cümlede Aziz Yıldırım değişimi açıklayarak tanımlama unsurundan yararlanmıştır. Tanımlamanın son cümlesinde ise her şey değişecek ifadesiyle alaya alma yani ironi unsurunu kullanmıştır.

(5) Bak çok ayıp ediyorsunuz diye başlayan paragrafta ise hiç affetmem ifadesiyle Aziz Yıldırım kongre üyeleri ve taraftarlar üzerinde korku ve endişe yaratmaya çalışmaktadır. (6) deşifre metninde altı ile numaralandırılmış paragrafta Aziz Yıldırım konuşmasını güçlendirmek için güvenilir kaynak olarak Yargıtay’ı kullanmaktadır. Söylemin devamında şimdi uğradığımız haksızlığın zulmün hesabı ortada duruyor cümlesinde ise zulmün hesabı ifadesiyle metafor unsurundan faydalanılmıştır.

(6) Elimizde bir yargı kararı olmaksızın yapacağımı her şey bir zorbalık olur paragrafinda hesap kişisel hesabım değil Fenerbahçe'nin hesabıdır ifadesinde Aziz Yıldırım mitonomi unsurundan yararlanmaktadır. İfadenin devamında Ali Yıldırım Koç'u 3 Temmuz sürecindeki tavrını eleştirmek için 101 kişinin Ali Yıldırım Koç için verdiği dilekçeleri örneklendirirken 101 kişi ifadesiyle rakamsal bilgiden faydalanılmıştır. Aynı cümle içerisinde Aziz Yıldırım, BIMMER ve CIMER'i güvenilir kaynak unsuru olarak kullanmıştır. O günden beri Ali Yıldırım Koç durumun ciddiyetini televizyon televizyon toplantı toplantı dolaşarak anlatıyor cümlesinde ise olayla ilgili arka plan bilgisine başvurulmuştur. $\mathrm{Bu}$ söylemden sonra Ali Yıldırım Koç'un bu olaylardan ötürü Fenerbahçe'nin hakkını savunamayacağını iddia ederek cümlenin sonunda hesabı sorabilir mi ifadesiyle alaya alma yani ironi unsuru kullanılmıştır. $\mathrm{Bu}$ paragrafın devamında başkan taraftarla söz dalaşına girerek kongre üyelerini eleştirmektedir. Aziz Yıldırım, kongre üyeleriyle tartışmasının devamında Fenerbahçe ile ilgili her şeyi kendisinin yaptığını vurgulamaktadır.

(7) Deşifre metninde yedi ile numaralandırılan paragrafta ben diyorum ile başlayan cümleden sonra 3 Temmuz zulmü ile beraber metafor kullanılmıştır. Cümlenin içerisinde paralel devlet veya düz devlet ifadesiyle beraber paralel yapılar kurulmuştur. Cümlenin içerisinde aynı zamanda olayla ilgili arkaplan bilgisi verilmiştir. Bu söylemin devamında Aziz Yıldırım, Ali Yıldırım Koç’u eleştirerek onu korkak olmakla suçlayarak eleştirmiştir. Aziz Yıldırım, paragrafın devamında ne biz böyle bir şeye tenezzül ederiz, ne de Fenerbahçelinin iftiraya maruz... ifadesiyle devam eden cümlede aynı şekilde paralel yapı kurulmuştur. Söylemin devamında Ali Yıldırım Koç’un ürkmesine, endişelenmesine gerek yoktur ifadesiyle sürü mantığının yanında aynı zaman alaya alma unsuru kullanılmıştır. Cümle içerisindeki en önemli ifadelerden birisi ise Aziz Yıldırım'ın bir kale gibi sorunların karşısında duracağını vurgulamasıdır. Aziz Yıldırım, kale söylemiyle metafor unsurunu kullanmıştır. Söylemin devamında Aziz Yıldırım, 3 Temmuz sürecinin ne kadar büyük bir etki yarattığını vurgulamak için deprem metaforunu kullanmıştır. Söylemin devamında arkaplan bilgisi verilerek, örnekler verilmiştir. Paragrafın sonunda Real Madrid takımıyla örnek verilmiştir.

(8) Real Madrid takımını düşünelim, bırakın Fenerbahçe'yi bir operasyon yapılıyor başkanı, yöneticileri ve profesyonelleri içeri giriyor paragrafinda Real Madrid takımından bahsederek örnek verilmiştir. Söylemin devamında 3 Temmuz'un yarattığı ekonomik etkiyi vurgulamak için en az 3 tam sezon vurgusuyla rakamsal bilgiden faydalanılmıştır. Söylemin devamında Real Madrid takımında oynayan Ronaldo, Marcelo ev Ramos gibi futbolculardan örnekler verilmiştir. Söylemin devamında feda dedirtmemek ifadesiyle kişiselleştirme retorik unsurundan yararlanılmıştır. Aziz Yıldırım, kendi yaptığı icraatları eleștirirken bazı hamlelerinin başarılı olduğunu, bazılarının da olmadığını ifade ederken paralel yapı kurmadan faydalanmıştır. Yıldırım, Fenerbahçe'ye yapılan haksızlıkları anlatırken benim karşımda devletin kurumları, hakimleri, savcıları, polisleri, UEFA, FIFA vardı cümlesinde devletin kurumları, hakimleri, savcıları, polisleri, UEFA, FIFA ifadeleriyle kanıt gösterme ve örnek verme 
unsurundan faydalanmıştır. Söylemin devamında Yıldırım, Nasreddin Hoca'yı örnek vererek ironiden yararlanmıştır. Paragrafın devamında mesele kendisini Fenerbahçe'den daha üstün, daha değerli görmelerini müsaade etmeyişimizdir cümlesinde olayın arkaplan bilgisi verilerek, örnek verilmiştir.

(9) Deşifre metninde dokuz ile numaralandırılan paragrafta gelelim başka kulüplere ile başlayan cümle de her zaman büyük taraftarıyla ezici bir güçtür ifadesinde metafor unsuru kullanılmıştır. Söylemin devamında Fenerbahçe'nin diğer kulüplerle ilişkileri anlatılırken örnek verilmiştir. Olayın inanılırlığını arttırmak için Yargıtay kurumu güvenilir kaynak olarak kullanılmıştır. Paragrafın devamında Ali Yıldırım Koç'tan bahsederken onun 3 Temmuz ile ilgili hesap soramayacağını bahsederek ironi yapmıştır. Futbol takımının o sezonki durumundan, tribünlerin bölünmesinden bahsederken 12. Adam ifadesiyle metafor kullanmıştır. Söylemin devamında sevgili kardeşim Ali ile başlayan cümlede Ali Yıldırım Koç’u suçlamaktadır ve cümlenin devamında ondokuz aydır kelimesiyle rakamsal bilgi kullanmıştır.

(10) Fenerbahçe'de bu büyük kurumsallık olmadığını, bu kurumsallığı getireceğini söylüyor. ile başlayan paragrafta biz ifadesiyle zamir kullanımları mevcuttur. Aziz Yıldırım, Fenerbahçe'ye kazandırdıklarını anlatırken diğer kulüplerin daha sonra da TFF'nin Fenerbahçe'nin kurumsal yapısını örnek aldığını ifade ederken güvenilir kaynak ve örnek verme olarak TFF kullanılmıştır. Yıldırım, bu cümle içerisinde kendi yaptıklarını ifade ederken sık sık kendini övmekte ve yüceltmektedir. Diğer kulüplerin devlet yardımlarıyla bir yere geldiğini ifade ederken şikenin tanımlamasını yapmaktadır. 3 Temmuz olayını anlatmaya devam ederken ekmeğine yağ sürdü ifadesiyle beraber hem benzetme hem de deyim kullanımı mevcuttur.

(11) Deşifre metninde onbir ile numaralandırılan paragrafta hedef 1 milyon üye projesi ile başlayan paragrafta tek adamlığı kuralını anlatırken aynı zamanda onu tanımlamaktadır. Tek adam yönetiminin getirdiği kurallardan doğan sonuçları anlatırken alaya alma başka bir ifadeyle ironiden yararlanılmıştır. Paragrafın sonunda yer alan bilmiyorlar ya da çabuk unuttular ifadesiyle paralel yapı kurmadan faydalanılmıştır.

(12) Peki o halde yeniden aday olmam, bir türlü görevi bırakmak istemeyişimin koltuktan ayrıl ayamamışımın anlamına $\mathrm{m} ı$ geliyor? ile başlayan paragrafta Yıldırım, çocuklar üzerinden örnekler vererek, kongre üyelerini korkutarak ancak sorunları kendisinin çözeceğini iddia etmektedir. Paragrafta şikeci diye alay edilen çocuklar ifadesinde örnek verilmiştir. Bu söylemden sonra ben vazgeçemem, vazgeçmeyeceğim ifadesiyle başlayan cümlede, tekrar vurgusu, mücadeleci ruhu ve güç vurgusu yapmaktadir.

(13) Deşifre metninde on üç ile numaralandırılmış paragrafta Fenerbahçe'yi namerde muhtaç etmedik ifadesinde benzetmeden yararlanılmıştır. Fenerbahçe'nin 3 Temmuz travmasını atlatmak için özeleştiri yapan Yıldırım, bu dönem içinde taraftarın moralini yükseltmek için yanlış kararlar verdiğini ifade etmektedir. Paragrafin son cümlesinde sen ne veriyorsan aynısını ben ve yönetimim koyacak cümlesinde zamir kullanımına yer verilmiştir.

(14) Ve ve sana teklifim paragrafinda Yıldırım, buyur buraya gel... ifadesinde rakibi Ali Yıldırım Koç'a meydan okumaktadır. Bu cümlenin devamında ne sen kazan ne ben ne sen ne ben ifadesinde hem paralel yapı kurma hem de zamir kullanımına yer verilmiştir.

(15) Demek ki, demek ki, demek ki ile başlayan paragrafta tekrarlama yapılmıştır. Tekrarlama vurgusundan sonra kendi başkanlığında geçen 20 yıllık süreçte rakamsal bilgi ve olayın arkaplanıyla ilgili bilgiler verilmiştir. Cümleden sonra kazanan Fenerbahçe olsun... ifadesinde mitonomi kullanılmıştır. Yıldırım, yönetim süresinde yaptığı icraatları vurgulamak için paragraf genelinde örnek vermeden yararlanmıştır. Paragrafın sonunda yer alan kendim için konuşmuyorum Fenerbahçe için... ifadesinde mitonomi kullanımı yer almaktadır. 
(16) Deşifre metninde on altı ile numaralandırılmış paragrafta Fenerbahçe'nin haysiyet bayrağını... ifadesinde metafor kullanımı mevcuttur. Bu ifadenin içerisinde Yıldırım ayrıca Ali Yıldırım Koç'a meydan okuyarak kulübün bir bölümünü kendisinin diğer bölümünü ise Koç’un yönetmesini teklif etmektedir. Bu cümleden sonra buyurun... ile başlayan cümlede Yıldırım, hem rakibine teklifte bulunmaktadır hem de meydan okumaktadır, cümlenin devamında turnusol ifadesinde metafor kullanımından yararlanmıştır. Yıldırım gücünü vurgulamak için son sözüm, son sözüm ... diye devam eden ifade de tekrarlama özelliğinden faydalanmıştır. 3 Temmuz kumpası... ile devam eden cümle de hem olayın arkaplan bilgisine başvurulmuş hem de kumpas ifadesiyle metafor kullanımından yararlanılmıştır. Yıldırım, ayrıca ben ve biz ifadeleriyle paragraf genelinde zamir kullanımından da yararlanmıștır. Paragrafın içerisinde yer alan son ifadelerde Yıldırım, metafor kullanımından yararlanmıştır. Burada metafor olarak seçtiği kelimeler ise nefer, dar ağacında olsak biledir. Ayrıca Yıldırım son sözüm Fenerbahçe ifadesinde sürü mantığı yaratma kuralından yararlanmaktadır.

(17) Sayln Ali Bey, sen 12 mayls 2012'de Aziz Yıldırım Metris hapishanesinde yatarken Fenerbahçe yönetiminde bu insanların çoğuyla beraber burada değil miydiniz paragrafinda olayın arkaplanı ile ilgili bilgi verilmektedir. Cümlenin devamında ben ifadesi sıklıkla kullanılarak zamir kullanımından yararlanılmıştır. Burada aynı zamanda Yıldırım, Koç’tan hesap sorarak karşılaştırmalar yapmaktadır. Bu söylemlerden sonra Yıldırım, 3 Temmuz ile başlayan cümlede 3 Temmuz'u vurgulamak ve güçlendirmek için 3 Temmuz tekrar tekrar kullanmaktadır. Bu cümlenin devamında gerçeklerin acı olduğunu ifade etmek için metafor kuralından faydalanmıştır. Dönemin Fenerbahçe oyuncuları olan Lugano, Santos gibi oyuncuların satışını eleştirmek bu futbolcuları örnek olarak göstermektedir. Bu paragrafin devamında Yıldırım, 3 Temmuz olayını ve futbolcuların önemini vurgulamak, Santos ve Lugano'yu tekrardan örnek olarak vermektedir. Bu söylemden sonra 5 milyon, 10 milyon ifadesiyle rakamsal bilgi ve olayın arkaplanıyla ilgili bilgiler vermektedir.

(18) Sen diyorsun ki... ile başlayan paragrafta Yıldırım, belirli sebeplerden ötürü sözleşmesini fesih ettiği Zico ile ilgili olayın arkaplan bilgisini ve olayı örnek vererek anlatmaktadır. Bu örneklerin devamında unutuyon ben unutmam... ifadesinde paralel yapı kurma özelliğinden yararlanılmıştır. Yıldırım'ın bak bir şey söyleyeceğim... ile başlayan ifadesinde Ali bey ve Alex isimlerini hem örnek verme olarak kullanmıştır hem de Alex'i mitonomi olarak kullanmıştır.

(19) Unutmayın, bakın ben o tribünlerden geldim... ifadesiyle başlayan paragrafta Yıldırım, Fenerbahçe kaptanlarından Ümit Özat'a yapılan olayı arkaplan bilgisini vermiştir. Yıldırım aynı zamanda Koç'un Özat'a haksızlık yaptığını belirtmek için Özat'ın ifadeleri söyleyerek onun telefon ile kongreye bağlanmasını hem teklif hem de şantaj olarak sunmaktadır. Yıldırım, bu paragrafta görüşlerini vurgulamak için tekrar özelliğinden yararlanmıştır.

(20) Federasyonla iyi geçinelim diyorsun paragrafinda Yıldırım neden federasyonla iyi geçinmeyeceğini olayın arkaplanıyla beraber örnek vererek açıklamaktadır. Cümlenin devamında İtalyan sportif direktör (Terranao) olayını anlatırken Fenerbahçe'nin eski yöneticilerinden Murat Özaydınlı'yı örnek olarak vermektedir. Yıldırım, Terranao olayının nasıl geliştiğini anlatmak için hem arkaplan bilgisinden hem de örnek verme kuralından yararlanarak kongre üyelerini ikna etmeye çalışmıştır.

(21) 1 milyon üye projesi yaptık... ile başlayan paragrafta Yıldırım, Koç'un projeye destek vermediğini vurgulamak için Koç'un da sahibi olduğu Arçelik ve Ford gibi şirketleri örnek göstermiştir. $\mathrm{Bu}$ söylemin devamında Ali Yıldırım Koç’un yönetim kurulu listesini eleştirmek için Yıldırım, Koç'un listesindeki iki tane arkadaş var... ifadesiyle örnek vererek ironi yapmıştır. Yıldırım görüşlerini güçlendirmek için iki yöneticiyle ilgili tekrarlar yapmıştır. Bir sonraki paragrafta lazım olur sana bak... ile başlayan cümlede Beşiktaş ve Galatasaray'dan örnekler veren Yıldırım, cümlenin devamında yer alan bir gün herkes Fenerbahçeli olacak... sloganıyla da mitonomi kuralından faydalanmıştır. 
(22) Deşifre metninde yirmi iki ile numaralandırılmış paragrafta bak şimdi... ile başlayan cümle de gülmem yoktu gülmeye başladım ifadesiyle Yıldırım alaya alma yani ironiden yararlanmıştır. Paragrafta görüşlerini vurgulamak için tekrar özelliğinden yararlanan Yıldırım, bir gün herkes Fenerbahçeli olacak sloganı tekrarlayarak Fenerbahçe'nin gücünü vurgulamıştır.

(23) Ben 1 milyon üyeyi... ile başlayan paragrafta Yıldırım, halka insin... ifadesiyle benzetmeden yararlanmıştır. Cümlenin devamında Fenerbahçe büyüklüğünü vurgulamak için Fenerbahçe seçimlerini Kızılay seçimlerine benzeterek olayın arkaplanıyla ilgili bilgiler vermektedir. Seçimlerle ilgili tüzük çalışmasında katılan Şekip bey, Vefa beyi isim vererek örnek olarak göstermiştir. Tüzük çalışmasına katılan 15-20 kişi ifadesiyle rakamsal bilgi kullanımından yararlanmıştır. Şimdi buradaki kaide... ile başlayan cümlede bir kişi Fenerbahçeliyim diyorsa ifadesinde mitonomi unsurundan yararlanılmıştır. Cümlenin devamında Yıldırım, özeleştiri yaparak hatalar yaptığını örnekler vererek kabul etmiştir. Yıldırım, paragrafın son cümlesinde Sinan Akfa ismini örnek vererek Ali Yıldırım Koç'u ve yönetim kurulu listesini de eleştirmiştir. Bir sonraki paragrafta Yıldırım, güvercin beslerim, bazen şans... ile başlayan cümlede metafor kullanımından yararlanmıştır.

(24) Bak şimdi, bu da mı üye değil... ile başlayan paragrafta Ali Yıldırım Koç yönetimindeki bir üyeyi (Burhan Karaçam) Galatasaraylı olmakla suçlamak için olayın arkaplan bilgisine başvurmuştur. Paragrafın devamında olayın arkaplanıyla ilgili bilgi vermeye devam ederek daha sonra Burhan beyin üyelikten ayrıldığını belirtmiştir. Yıldırım, Fenerbahçe'nin büyüklüğünü, yüceliğini övmek içinde yaptığı kongreyi örnek olarak göstermiştir. Yıldırım, son paragrafta her şeyi kendisinin yaptığını vurgulayarak, tarihin kendisini yazacağını ve herkesin onu hatırlayacağını söyleyerek konuşmasını bitirmiştir.

\subsection{Ali Yıldırım Koç’un Konuşmasının Retoriksel Çözümlenmesi}

Fenerbahçe Spor Kulübü başkan adayı Ali Yıldırım Koç’un 2 Haziran 2018 tarihinde yapmış olduğu konuşmasının retoriksel açıdan değerlendirilmesinde sıklıkla örnek verme, metafor kullanımı, arkaplan bilgisi ve güvenilir kaynak kullanımı yer almaktadır. Ayrıca, mitonomi, zamir kullanma, methiye, güvenilir kaynak kullanımı, sürü mantığı yaratma, alaya alma üçleme kuralına uyma, rakamsal bilgi verme v.b öğeler de zaman zaman konuşma içerisinde kullanılmaktadır.

Başkan adayı konuşmasının başlangıcında güncel bir olaya atıfta bulunmakta, şehit düşen 3 askerimize rahmet ve yakınlarına sabır dilemektedir. Konuşma metninin paragrafları tek tek değerlendirmeye alındığında, ilk paragrafta Ali Yıldırım Koç’un genel örnekler vererek Aziz Yıldırım'a yaptığı methiye ve teşekkür söylemleri, saygı ifadeleri yer almaktadır. Koç, arkaplan bilgisi olarak 3 Temmuz olayını hafizalarda canlandırmaya çalışmakta, o dönemde duruşu ve kulübü, camiayı sahiplenişi açısından Yıldırım'a methiye ve övgü ifadeleri göndermektedir. Örneğin Aklı olan her Fenerbahçeli size bu süreçte başta türk sporuna katkılarınız ama özellikle de 3 Temmuzdaki büyük cesaretiniz ve dik duruşunuz için daima müteşekkir olacaktır. söylemlerinde teşekkür ve minnettarlık ifadeleri dikkat çekmektedir. Ayrıca 'bizler de o dönemde size ve kulübümüze sahip çıkmak için her şeyi yaptık... 'örneklerini vererek, dönem içerisinde kendi hareket ve tutumlarına yönelik olumlu, destekçi söylem ortaya koymaya çalışmaktadır.

2. paragrafta Koç genel bir kıyaslama ekseninde Aziz Yıldırım ve kendi ifadelerinin birbirinden oldukça farklı olduğunu dile getirmekte, 'siyahla beyaz kadar' metaforu ile eleştirel ifadeler kullanmaktadır. ... her zaman bu konuda kendi söylediklerime, bildiklerime inanarak böyle bir çağrıda bulundum. Ama siz yanaşmadınız. Örneğinde ise kendi çağrısına olumsuz yaklaşan Yıldırım'1 suçlayarak eleştirmektedir.

3.paragrafta ifadeleri '49 ayrı etkinliğe katıldık' v.b rakamsal bilgilerle desteklemekte, kulübün geleceğine yönelik özlenen Fenerbahçe benzetmeleriyle camiaya olan bakış açısını ortaya koymaktadır. Değişim, dönüşüm ve sürdürülebilirlik ifadeleri üzerinde sıklıkla duran Ali Yıldırım Koç, kulübün 
geleceğine yönelik belirledikleri hedefleri açıklamaktadır. Köklü değişimlerin olması gerekliliğine işaret eden Koç, 'derin yara' metaforu üzerinden ve Fenerbahçe bir bütündür mitonomisini kullanarak parçalar üzerinden sağlanacak olan bir birleşme ve toplu hareketi ifade etmektedir. Dolayıslyla öncelikli eleştirilerimi finansal sıkıntılar ya da sportif konulara dair değil ama bunlardan çok ama çok çok daha vahim olan bir başka derin yaramız üzerinden hitap edicem, anlatmaya çalışcam örneğinde yer aldığı gibi birçok yerde Aziz Yıldırım'ın insan faktörünü dikkate almayışı eleştirilmektedir. İlk başkanı Ziya Songülenden, ilk efsane santroforumuz Zeki Rıza Sporele Fikret Kırcandan Leftere Puşkaş Ergundan Ogün'e Cemilden Revivodan Boliçe Selçuğa Hooijdonktan Alexe Zicodan Ersun Yanala Aykut Kocamana tüm bu isimler ve yaşanan örnek olaylar çerçevesinde geçmişe yönelik atıflarda bulunularak hatırlatmalar yapılmaktadır. Yıldırım'ın her şeyi ve her konuyu kendini önplana çıkarak ortaya koyma şekli Siz kendi doğrularınıza göre, yorumlarınıza göre kendi iliş̧i ve kararlarınıza göre Fenerbahçe tarihinin işinize gelmeyen bölümlerini görmezden geldiniz yok saydınız. Her başarıyı hep ben diyerek sahiplendiniz. Fakat her başarısızlı̆̆ hep başkalarına faturaladınız. Son olarak bu sene kaçan şampiyonluğu da kendiniz hariç ben dahil herkesi sorumlu tuttunuz. ve Her başartyı hep ben diyerek sahiplendiniz. Fakat her başarısızlı̆̆ hep başkalarına faturaladınız. Son olarak bu sene kaçan şampiyonluğu da kendiniz hariç ben dahil herkesi sorumlu tuttunuz. ifadeleriyle eleştirilmektedir. Ayrıca 'Alex Souza' mevzusu aynı konu çerçevesinde arkaplan bilgileri verilerek aktarılmaktadır. Bu noktada Koç, Yıldırım'ın tutumunu sert bir şekilde eleştirmekte, Alex'in gönderilme şeklinin, birçok futbolcu ve teknik direktörün gönderilme şeklinin tamamen hatalı olduğunu vurgulamaktadır. Tüm bu olayların sorumlusu olarak Yıldırım'1 işaret etmektedir. Paragrafın devamında Içerdeydim tam duyamadım ama bir konuşmacı daha bu noktaya değindi. Ben de değinmek istiyorum. İfadelerinde ise zamir kullanımı ve örnek verme ve kanıt gösterme öğeleri yer almaktadır. Alex'in ve daha birçok efsanevi futbolcunun hiçbir şeklide camianın gönlünden silinemeyeceğini özellikle açıklayan Koç, Fenerbahçeli eski futbolcuların isimlerini kullanarak, örnek göstererek övgü ve methiyelerde bulunmaktadır. Paragrafın son bölümünde ise tamamen Aziz Yıldırım'ın futbolcuları ve direktörleri gönderme biçimi tartışılmaktadır. Birçok eleştirel ve suçlayıcı söylemler dikkat çekmektedir. Ali Yıldırım Koç Yıldırım'ı birçok futbolcuyu gönderirken camiayı ve özellikle de çocuk kitleyi kırmak ve üzmekle suçlamaktadır. Ardından, Son 6 seneye yönelik gerçekleşen olayları kıyaslayan ve özeleştiri yapan Ali Yıldırım Koç'un, Aziz Yıldırım'ın futbolculara, teknik direktörlere davranış biçimine, gönderimlerde yapılan tutumlara ve sürekli ben merkezci söylemlerin önplanda tutulmasına yönelik eleştirileri göze çarpmaktadır.

5. paragrafta kıyaslama yapılarak iyi bir başkanın özellikleri ve Aziz Yldırım'ın yapması gerekenler çerçevesinde çeşitli suçlamalar gerçekleştirilmektedir. Burada birçok arkaplan bilgisi kullanılmaktadır. Hep kötü futbolcular, kötü teknik direktörler, kötü insanlar üçlemesinde de Aziz Yıldırım'ın özeleştiri yapması gerekliliği üzerinde durulmaktadır. Bu noktada Koç kendi söylemlerine yönelik öz eleştirel er de yapmaktadır. Alaycı kinayeli ifadeler göze çarpmaktadır. Paragrafın sonunda kendinize yapılmasını istemediğiniz şeyi başkalarına yapmayın söylemleri Yıldırım’a yönelik eleştirileri ortaya koymaktadir.

6. paragrafta Allah her zaman doğrunun ve iyinin yanındadır ifadelerinde dinsel söylemlerin önplana çıkarıldığı görülmektedir. Doğruluk, iyilik, kavramları vurgulanmaktadır. Sadece küfüre karşıyız demekle yeterli olunamayacağını, insancıl ve saygı dolu hareketlerin de kullanılması gerekliği savunulmaktadır.

7. paragrafta 'kan davası' metaforu kullanılmakta yaşanan gerginlikler ve olumsuzluklar üzerinde durulmaktadır. Küfür olaylarını tekrar hatırlatan ve kınadığını olmaması gerektiğini belirten Koç ayrıca kin tutmanın da zararlarından bahsetmektedir. Sponsorlukları kişiselleştirmekte ve bir markaya yığılmaktan çekinmeye başlamasına da serzenişte bulunmaktadır. Konuşmanın devamı taraftarları yücelten söylemler içermektedir. Bir kulübü taraftarları taşır ve yüceltir. Taraftarlar her zaman hancı geri kalan her şey yolcu söylemin de metaforlar kullanmaktadır. Bu noktada taraftarların 
küstürülmesine yönelik eleştiriler yapan Koç, olumsuz olaylara atıfta bulunarak taraftarları övmekte ve methiye dolu destekçi söylemler kullanmaktadır. Bu bağlamda Yıldırım'ın. Bir televizyon kanalında taraftar polemiğine yönelik açıklamalarındaki önümüzdeki sezon tribünlerle ben ilgileneceğim ben tasarlayacağım dediniz. Taraftar tirübüne gelmezse yenilerini getiririm dediniz ifadelerini aktarmakta ve olayı Hayretlerle izledim. İnanamadım kulaklarıma. Hangi yenilerini getireceğiz sözleriyle şiddetle kınamakta ve eleştirmektedir.

8.paragrafta kongre üyelerine seslenen konuşmacı, yapılan yanlışlıklar, gecikmeler, hatalı transferler ekseninde külünün uğradığı zararları ortaya koymaktadır. Koç sürekli olarak denge, süreklilik, sürdürülebilirlik kavramlarını öne çıkararak sık sık geçmişe olan özlem duygularını ifade ederek duygusal yaklaşımlarda bulunmakta ve arkaplan bilgileriyle yaklaşımlarını desteklemektedir. 'Kanı lacivert akan' metaforunda tarihimizi ezbere bilen gençler yetiştirme arzusu, A takımına süreklilik kazandırma hedefi dile getirilmektedir. Tuncay, Salih Uçarlar isimleri kullanılarak geçmişe yönelik hatırlatmalarda övgü ve methiyelerde bulunulmaktadır. Ayrıca dünyanın en büyük takımı olarak gösterilen Barcelona örneği ve Fenerbahçe Kulübü'ne yönelik kıyaslamalarda Barcelona'nın gücünün arkasında yatan şeyin salt dinamik bir temel kadro oluşturulmasından kaynaklandığ 1 belirtilmektedir. Yine istikrar ve sürdürülebilirlik öğeleri tekrarlanarak başarının bu araçlardan geçtiği işaret edilmektedir. Konuşmanın devamında Aziz Başkan'a yönelik eleştiriler tekrarlanmakta başkanın açıklamaları örnek olarak gösterilmektedir. Ali Yıldırım Koç, Bu konular size sorulduğu zaman yine bir televizyon kanalında, ben iki senedir futbolla ilgilenmedim dediniz. Bunun altından şöyle bir mesaj çıkıyor. Illgilenseydim daha başarılı olurduk iması çıkıyor. Doğrudur. O zaman keşke ilgilenseydiniz Sayın Başkan. Siz bu kulübün başkanı değil misiniz? Amiral Geminiz futbol değil mi? sözlerinde amiral gemisi’ metaforunu kullanmakta, ifadelerdeki suçlayıcı söylemler, kinayeci, suçlayıcı anlatım dikkat çekmektedir. Ayrıca Van Persie ve sakat transferler olayı vurgulanarak suçlamalar desteklenmektedir.

9. paragrafta Ali Yıldırım Koç dinleyicilere kutsal görev metaforunu vurgulayarak, kendisinin başkan seçilme durumunda, göreve layık görüldüğ̈̈ takdirde ortaya koyacağı misyon ve vizyonları açıklamaktadır. Bu noktada eski yönetimle yeni hedefler arasında arkaplan bilgileri üzerinden yapılan kıyaslamalar dikkat çekmektedir. Mentalite farklılığı, özeleştiri yapma, rasyonel ve tutarlı olma kavramlarının yeni yönetimin hedefleri olduğu açıkça belirtilmektedir. Terminatör ruh hali metaforu ile eski yönetime gönderme yapılarak sürekliliğin sağlanamaması eleştirilmektedir. Ayrıca, Serkan Acar örneği hatırlatılarak övgü ve methiye söylemleri kullanılmaktadır

10. paragrafta değerli kongre üyeleri şeklinde devam eden konuşmada vaatler önplanda tutulmaktadır. Konuşmacı bu noktada huzurlu yaşamın, demokratik, baskısız, hesap veren yeni bir anlayışın hakim olacağının sözünü vermektedir. 'Fenerbahçe'nin kırmızı çizgisi' metaforuyla 3 Temmuz olayı tekrar gündeme getirilmektedir. Konuyu hafife almadığını belirtmek için dilimde tüy bitti benzetmesini yapan Koç, beklenilmeyen bir durumda aynı sonuçta aynı refleksi kullanacaklarını önemle ifade etmektedir. Yıldırım'ın Yargıtay Kararı üzerinden kendisine yaptığı suçlamaları eleştirerek, onu adalete karşı saygısızlıkla suçlamaktadır. Aziz Yıldırım'ın tutarsız hareket ettiğini de belirten Koç, daha önce eleştirdiği insanların onun yanında durduğunu ifade etmektedir. Beni Kaçmayla ima ettiniz. Sonra yanımdaydı dediniz. sık sı bu konuda fikir değiştiriyorsunuz ifadelerinde olduğu gibi bu yaklaşımlarını eleştirmekte ve onu vicdanlı ve adil yaklaşmaya davet etmektedir. . Herkesin bu mücadeleyi sonuna kadar vereceğini söyleyen konuşmacı, 'kafa sokacağını' ifadesindeki kafa sokma metaforunda, nasıl bir tutum sergileyeceğini açıķa göstermektedir. Yaklaşım biçimi, yönetim mentalitesi ve yönetim şekli üçlemesini yineleyen konuşmacı, 3 Temmuz olayını arkaplan bilgileri üzerinden değerlendirirken, yeni sayfa açma, yeni hikayeler başlatma konusunda barışçıl söylemler kullanmaktadır.

11. paragrafta Sizler ve büyük Fenerbahçe taraftarına sonuna kadar güveniyorum mesajıyla taraftara inanç ve güven söylemleri üzerinden üstü kapalı misyonlar yüklemektedir. Dikenli Yol metaforunda taraftarların güçlü bir şekilde beraber hareket etmesi gerekliliğini vurgulamakta, bir bütün olma Fenerbahçeli olmak mitonomisi, birken bütün olmak ifadeleriyle sağlanmaya çalışılmaktadır. 
Allah'ın takdiri dinsel söylemini de ara ara tekrarlamaktadır. Güven ve umut kavramları ekseninde taraftara layık olma korkusu üzerinde durulmaktadır. İnşallah hep beraber çok güzel günler göreceğiz ifadeleri; Belki yarın belki yarından da yakın metaforuyla İstiklal Marşı'nın gücü ve kudretine gönderme yapilmaktadır.

Son paragrafta iftira ve iddialar üzerinden Aziz Yıldırım'ın kendisini itibarsızlaştırmaya çalıştı̆̆ını öne süren Ali Yıldırım Koç, Yıldırım'ı suçlayarak Yıldırım'ın kendisi ve taraftarla arasındaki güçlü bağı asla koparamayacağının garantisini vermektedir. Arkaplan bilgisi olarak Yüksek Divan Kurulu seçimlerini hatırlatan konuşmacı, nasıl titizlikle ve ayrıntılı olarak çalıştıklarını önemle vurgulamaktadır. Fenerbahçeliyiz.net e mail adresini kanıt göstererek, örnekler vermektedir.' Evet Başkanım, hem açık ortamlarda yani açık ortamlarda farklı, kapılı ortamlarda farklı konuşuyorsunuz 'ifadelerinde Aziz Yıldırım'ın tutarsızlıklarını yinelemektedir. Konuşmada Ali Yıldırım Koç'un sitem içeren ifadeleri dikkat çekmektedir. Koç'a göre insan en çok, sevdiğinden, saydığından, sıkı sıkıya tutkulu olduğundan, sadık olduğundan zarar gördüğünde üzülür. Bu durumu, 'kalbimin bir parçasının koptuğunu' metaforu ve kişiselleştirmesiyle dile getiren Koç, Yıldırım'a bir şey olursa ilk kendisinin yanında olacağını belirterek duygusal ifadelere yer vermektedir. Son olarak, 'aynı gemide yer almak' metaforu birliktelik, 'sapla samanı birbirine karıştırmama' benzetmesi ile doğru analiz ve değerlendirme yapma konularını vurgulamaktadır. 'Kim kazanırsa kazansın, hepimiz Fenerbahçe için buradayız' mitonomisi ve her anlamda biz farklıyız, 'seçimiz de farklı, büyüklüğümüz de farklı, sevgimiz saygımız da farklı' üçlemesi kullanılmaktadır. Koç ayrıca konuşmasına son verirken Ali Şen örneği ve New York Times mevzusu üzerinden kanıt göstermekte ve eleştiri yapmaktadır.

\section{Sonuc}

Günlük yaşantımızda, sosyal ilişkilerimizde iknanın önemi giderek artmaktadır. Yaşamımızın herhangi bir döneminde mutlaka karşı tarafı ikna etmeye yönelik çabalarımız olmuştur. Bazılarımız yaşam pratiklerimizde, bazılarımız ise iş hayatımızın bir gereği olarak ikna etmeyle karşı karşıya kalmaktadır. İletişim ve ikna birbirini tamamlayan iki unsur olarak karşımıza çıkmaktadır. İletişim temel anlamda herhangi bir mesajın birine veya bir kuruma başarılı bir şekilde ulaştırılması olarak tanımlanabilir. Bu süreçte alınan geri bildirim ile iletişimin başarılı olup olmadığı anlaşılabilmektedir. İkna ise kısaca karşı tarafı etkileme eylemidir. İnsanlar çeşitli ikna yöntemleri sayesinde kişilerin düşüncelerini değiştirebilir, bir ürünü pazarlayabilir ya da gerçek dışı bir olayı gerçekmiş gibi karşı tarafi inandırabilir. Ancak ikna gerçekleri değiştiremez sadece manipüle edebilir. Bununla birlikte ikna, gerçekliklere verilen anlamları değiştirerek onları daha önemli veya daha önemsiz hale getirebilir. Retorik ise bir ikna etme sanatıdır. İnsanlarda düşünce davranış değişikliği sağlamak için dilin etkili bir şekilde kullanılmasıdır. Kısaca hitabet sanatıdır.

İknanın temel amacı etkili olmayı öğrenmektir. Bir insanı ikna etmek için öncelikli olarak o kişiyi veya grubu ikna olmaya hazır hale getirmek gerekir. İnsanlara ileteceğimiz mesajı kabul ettirmemiz, belirli tutum değişiklikleriyle sağlanabilir. İkna kavramındaki güven ve inandırıcılık unsuru arttırılarak karşıdaki kişiler istenilen yöne çekilebilmektedir. Bu noktada özellikle reklam ve pazarlama alanının vazgeçilmez bir unsurudur. Birçok kurum ilgili alanda ikna stratejileri, etkili sunum teknikleri, hitabet, retorikle ilgili eğitim seminerleri düzenleyerek bireyleri yetiştirmektedir.

İş hayatında olduğu gibi politika, spor, eğitim alanında hitap etmek ve belirli bir kitleyi etki altına almak oldukça büyük bir önem taşımaktadır. Spor birçok kitleyi bir araya getiren, ekonomik, politik, psikolojik açıdan yönlendiren bir alandır. Sporun içerisinde futbolun önemi tartışılmaz bir gerçektir. Birçok kitle futbol söylemi ekseninde seyirci ya da oyuncu olarak bir araya gelmektedir. Bu bağlamda kulüpler, kulüp başkanları ve yöneticileri de taraftarları etki altına almak ve istedikleri şekilde yönlendirmek için futbolun gücünden yararlanabilmektedir. Dönem dönem yapılan açılış konuşmaları, maç öncesi ve sonrası verilen demeçler, kongre süreçlerinde yapılan açıklamalarda hitabet gücü kullanılmakta ve iknanın öneminin giderek arttığı görülmektedir. 
Çalışmada 20 yıla yakın bir süre Türkiye'nin en büyük sivil toplum örgütlerinden Fenerbahçe Spor Kulübü mevcut başkanıyla, Türkiye'nin en önemli holdinglerinden biri olan Koç Holding Yönetim Kurulu Başkan Vekili Ali Yıldırım Koç’un, 2-3 Haziran 2018 tarihinde Fenerbahçe Spor Kulübü Olağan Seçimli Kongresinde yaptıkları konuşmalar retoriksel açıdan analiz edilmiştir.

Aziz Yıldırım konuşmasında genel olarak 3 Temmuz'da yaşanan şike olayları sürecine değinmektedir. 3 Temmuz sürecinde kendisinin bir yıl hapis yattığını vurgulamaktadır. Bu süreçten sonra camianın bozulan moralini düzeltmek için bazen yanlış kararlar verdiğini vurgulayan Yıldırım, burada bir özeleştiri de yapmıştır. Yıldırım konuşmasında özellikle her şeyi kendisinin yaptığını sıklıkla vurgulamaktadır. Ayrıca yapılan tüm hatalarda da başkalarını suçlu bularak, onları kulüpten itibarsızlaştırarak göndermiştir. Yıldırım'ın, konuşmasında en çok kullandığı retoriksel unsurlar metafor, örnek verme, araka plan bilgisi, güvenilir kaynak ve benzetmedir. Bunların dışında Yıldırım sıklıkla zamir, alaya alma, mitonomi, rakamsal bilgi vb. unsurları kullanmıştır. Bazı bölümlerde ise muhalefet ile kendini karşılaştırarak farklı bir tablo çizmeye ve kongre üyelerini ikna etmeye çalışmaktadır. Başkan konuşması boyunca sık sık kongre üyeleri ile sözlü olarak tartışarak konuşmasına ara vermektedir.

Ali Yıldırım Koç, konuşmasında temel olarak geçmiş yönetimin hatalarından bahsetmekte ve kendisinin seçilmesi durumunda yeni yönetimin ortaya koyacağ bahsetmektedir. Bu bağlamda en çok kullandığı kavramlar sürdürülebilirlik, denge ve sürekliliktir. Ayrıca Koç, yeni yönetimin farklı mentalite anlayışından söz ederken, özeleştiri yapan, rasyonel ve tutarlı, demokratik, hesap veren ve baskısız yeni bir dönemin açılacağına işaret etmektedir. Koç'un söylemlerinde eleştirel ve suçlayıcı bir tutum sergilediği görülmektedir. Özellikle Yıldırım'ın insan unsurunu dikkate almayışı, futbolcuları, teknik direktörleri gönderiş biçimi ve sürekli olarak tekrarladığı ben merkezci ifadeler eleştiri noktalarının temelini oluşturmaktadır. Koç bu noktada dönem içerisinde kendinin de dahil olduğu karar verme süreçlerinde de özeleştiri yapmaktadır. Konuşmalarda en çok metafor, örnek verme, arkaplan bilgisi unsurlarını kullanan başkan adayı sıklıkla mitonomi, zamir kullanma, methiye, güvenilir kaynak kullanımı, sürü mantığı yaratma, alaya alma üçleme kuralına uyma, rakamsal bilgi verme vb. ögeler de zaman zaman konuşma içerisinde kullanılmaktadır.

Bu çalışmada Ali Yıldırım Koç’un geleceğe yönelik vaatlerinde değişim, süreklilik, barış kavramlarını sürekli olarak yinelemesi ve yaptığı özeleştiriler ikna edici iletişim yolunda başarılı bir strateji olarak görülmektedir. Aziz Yıldırım'ın ise ben merkezli söylemleri sıklıkla tekrar etmesi, geçmiş dönemde yapılan hataları başkalarının üstüne yüklemesi ve agresif tutumlar sergilemesi ikna edici iletişimde stratejik olarak hatalı görülen tutumlar arasında yer almaktadır. Her iki konuşmacı da konuşmalarında sıklıkla örnek verme, kanıt gösterme, metafor kullanımı, güvenilir kaynak kullanımı ve arka plan bilgi verme yöntemlerini kullanmaktadır. Seçim sürecindeki çalışmaların sonucunda Ali Yıldırım Koç Fenerbahçe Spor Kulübü Başkanı seçilmiştir.

\section{KAYNAKÇA}

Adair, J. (2013). Etkili İletişsim. İstanbul: Babıali Kültür Yayıncılı̆̆ı.

Aristoteles. (2001). Retorik. İstanbul: Yapı Kredi Kültür Snat Yayıncılık.

Arkonaç, S. A. (2001). Sosyal Psikoloji. İstanbul: Alfa.

Aziz, A. (2013). İletişime Giriş. İstanbul: Hiperlink Yayınları.

Bıçakçı, A. B. (2012). İkna Edici İletişim ve Retorik Analizi. Ö. Güllüoğlu içinde, İletissim Bilimlerinde Araştırma Yöntemleri Yazılı Metin Çözümleme (s. 334-361). Ankara : Ütopya Yayınevi.

Bir, A. A. (2005). İkna ve Konuşma. Eskişehir: Anadolu Üniversitesi Açıöğretim Yayınları. 
Bourse , M., \& Yücel, H. (2012). İletişim Bilimlerinin Serüveni. İstanbul: Ayrıntı Yayınları.

Burgin, V. (tarih yok). Fotoğrafi Düşünmek. Espas Yayınları.

Devran, Y. (2010). Haber Söylem İdeoloji. İstanbul: Başl1k Yayın Grubu.

Elden, M., \& Bakır, U. (2010). Reklam Çekicilikleri Cinsellik, Mizah, Korku. İstanbul: İletişim.

İlal, E. (1997). İletişim Ylğınsal İletim Araçları ve Toplum. İstanbul: Der Yayınları.

Küçükerdoğan, R. (2011). Reklama Nasıl Çözümlenir?Reklam Illetişiminde Göstergeler ve Stratejiler. İstanbul: Beta Yayınlar1.

Karadoğan, E. S. (2003). Kişiler Arası İletişim Sürecinde Güven Unsuru Güven İkna Ölçeği Örneği. İstanbul: İstanbul Üniversitesi Sosyal Bilimler Enstitüsü Tanıtım ve Halkla İlişkiler Anabilim Dalı Yayımlanmamış Doktora Tezi.

Mısırlı, İ. (2011). Genel ve Teknik İletişim Kavramlar-İlkeler--Uygulamalar. İstanbul: Detay Yayınc1lık.

O'Keefe, D. J. (2002). Persuasion Theory \& Research. London: Sage Publications.

Perloff, R. M. (2007). The Dynamics of Persuasion : Communication and Attitudes in the 21st Century. New York, United States: Taylor \& Francis Inc.

Severin, W. J., \& Tankard, J. W. (1994). Illetişim Kuramları Kökenleri, Yöntemleri ve Kitle Iletişim Araçlarında Kullanımları. Eskişehir: Anadolu Üniversitesi (Longman Publishing).

Suler, J., \& Zakia, R. D. (2018). Görme Biçimi Olarak Fotoğraf Algılama ve Görüntüleme. İstanbul: The Kitap .

Türkiye Gazetesi. (2018, June 3). Aziz Yıldırım Kongre Konuşması. Türkiye Gazetesi Spor: https://www.youtube.com/watch? $\mathrm{v}=\mathrm{abGUxKNO0fQ} \& \mathrm{t}=4 \mathrm{~s}$ adresinden alınd 1

Tekinalp, Ş. (2016). Güzel Konuşma Bir Markadır Kişisel Gelişim ve İkna Yöntemleri. İstanbul: Beta Yayınlar1.

Tivibu Spor. (2018, June 2). Ali Koç'un Fenerbahçe Seçimli Olağan Genel Kurulu Konuşması. Tivibu Spor: https://www.youtube.com/watch?v=zS11U89bhvc adresinden alınd

Yıldırım, G. (2018). İkna Odaklı Halkla İlişkiler Yazarlı̆̆ı. İstanbul: Beta Yayınları.

Zıllığlu, M. (2003). İletişim Nedir? İstanbul: Cem Yayınevi. 